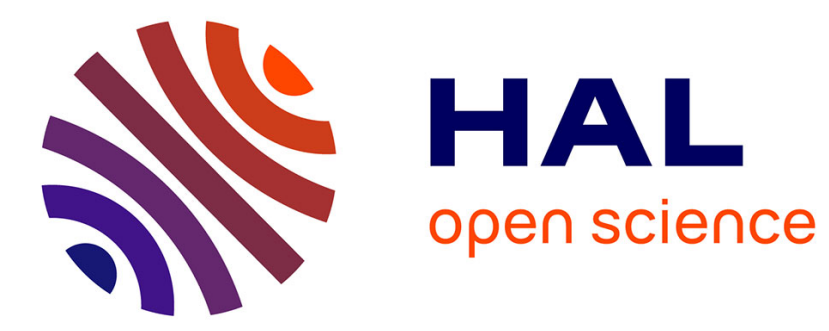

\title{
Electrochemical stripping analysis from micro-counter electrode
}

\author{
Qiao Liu, Liang Liu, Michel Perdicakis, Alain Walcarius
}

\section{To cite this version:}

Qiao Liu, Liang Liu, Michel Perdicakis, Alain Walcarius. Electrochemical stripping analysis from micro-counter electrode. Electrochimica Acta, 2021, 393, pp.139095. 10.1016/j.electacta.2021.139095 . hal-03355545

\section{HAL Id: hal-03355545 \\ https://hal.univ-lorraine.fr/hal-03355545}

Submitted on 27 Sep 2021

HAL is a multi-disciplinary open access archive for the deposit and dissemination of scientific research documents, whether they are published or not. The documents may come from teaching and research institutions in France or abroad, or from public or private research centers.
L'archive ouverte pluridisciplinaire HAL, est destinée au dépôt et à la diffusion de documents scientifiques de niveau recherche, publiés ou non, émanant des établissements d'enseignement et de recherche français ou étrangers, des laboratoires publics ou privés.

\section{(ㅇ)(1) $\$$}

Distributed under a Creative Commons Attribution - NonCommercial - NoDerivatives $\mid 4.0$ 


\title{
Electrochemical stripping analysis from micro-counter electrode
}

\author{
Qiao Liu, Liang Liu, Michel Perdicakis, Alain Walcarius* \\ Université de Lorraine, CNRS, Laboratoire de Chimie Physique et Microbiologie pour les \\ Matériaux et l'Environnement (LCPME), F-54000 Nancy, France
}

*Email: alain.walcarius@univ-lorraine.fr

\begin{abstract}
Electrochemical stripping analysis (anodic, cathodic, or adsorptive) is usually based on the preconcentration of a target analyte on the working electrode surface and then measuring its quantity via its direct quantitative electrochemical transformation (with the electrode refreshed afterwards). In this work, we demonstrate a new approach to carry out electrochemical stripping analysis of non-adsorbing species, thus not based on the analyte being directly preconcentrated on the working electrode (WE), but on the signal obtained indirectly from the counter electrode (CE) where metal ions are reduced and then electrochemically stripped. Different from the CE with large surface area in classical electrochemical measurements, an ultramicroelectrode is chosen here as $\mathrm{CE}$ to purposely exploit the polarization effect. The concept is based on oxidizing the analyte on WE in one compartment of the electrochemical cell while reducing $\mathrm{Cu}^{2+}$ on $\mathrm{CE}$ from another compartment connected with an ionic bridge or a less common metal "bridge". The deposited $\mathrm{Cu}$ on $\mathrm{CE}$ is then analyzed by stripping in another three-electrode cell, and the charge shows good linear relationship with the concentration of analyte in the former cell. As the stripping current response (peak) is much clearer than the small current variations corresponding to the direct oxidation of the analyte, it improves the resolution of raw signal. Besides, it may also reduce the background signal from blank solution by "filtering" the non-Faradaic charge. Like in classical electrochemical stripping analysis, one may also prolong the oxidation time in exchange for higher sensitivity of analysis. This work extends the applications of stripping analysis and offers a new angle of electroanalysis by capturing signals from counter electrode.
\end{abstract}

Keywords: indirect electrochemical stripping analysis; counter-electrode electrochemistry; voltammetry; amperometry. 


\section{Introduction}

Electrochemical analysis is an important domain in electrochemistry and analytical chemistry $[1,2]$. It directly converts chemical information such as concentration to electronic signals (potential or current) that can be read by modern instrumentation [3-5]. For example, potentiometry measures the equilibrium potential without any excitation signal and it is a common method for measuring $\mathrm{pH}$ and concentration of various ions $\left(\mathrm{Na}^{+}, \mathrm{K}^{+}, \mathrm{Ca}^{+}, \mathrm{Cl}^{-}\right.$, etc.) using ion-selective electrodes [6,7]. Amperometry and voltammetry apply a potential signal and record the current response. Depending on the waveform of the applied potential, the electrochemical analysis can be in time (chrono methods) [8,9], frequency (AC methods) $[8,10]$ or potential (cyclic voltammetry) domain [11-13]. Pulse or square wave voltammetry is often used to improve the sensitivity of such dynamic methods of electroanalysis [9,13-15]. Needless to say, electrochemical analysis has been widely applied in environmental analysis and biosensing [15-17].

Nevertheless, electrochemical analysis is often regarded as a cheap alternative of competing analytical methods, notably chromatography and mass spectrometry. The highlight is usually on the cost and ease of operation, rather than analytical aspects of sensitivity, selectivity, and reproducibility. A typical example is household glucose sensor [18], which is perhaps the most successful (bio)electrochemical sensor in the market [19] even though it may never provide the same information and accuracy as professional blood analysis in laboratories [20].

Electrochemical stripping analysis is an exception, where the sensitivity is the highest among all analytical methods for some analytes that are likely to be accumulated onto the electrode surface prior to their detection [21,22]. It originates from the analysis of heavy metal ions, where a pre-concentration is achieved by electrodeposition on the working electrode (WE) and then the quantity of electrodeposited metal is analyzed by the charge in anodic dissolution and can be related to the metal ions concentration in solution $[22,23]$. The pre-concentration can also be carried out based on electrostatic interactions or chemical adsorption between the analyte and the WE, which extends the applications also to non-metal species [24,25]. As the key to the method is on the pre-concentration, enormous effort has been made to push the lower detection limit by chemically modifying the WE to enhance the interactions with the analyte (e.g., via electrostatic interactions, complex formation, specific molecular recognition, or formation of sparingly-soluble species) [26-29]. A prerequisite to ensure high sensitivity is also that the accumulated species must be electrochemically accessible, in a fast and 
quantitative way, which might be intricate in some cases (electrode modifiers based on molecularly imprinted polymers, for instance) [30,31]. So far, anodic, cathodic and adsorptive/extractive stripping voltammetry remain among the analytical standards for the detection of trace elements and organic substances in the environment or in industrial samples belonging to food or pharmaceuticals sectors [25,32-35]. However, despite the high sensitivity, electrochemical stripping analysis is only applicable to the analytes that can be deposited or adsorbed onto, or have strong interactions with, the (modified) WE. A question then arises: How to extend the strategy of stripping to the analytes that do not pre-concentrate on WE?

Meanwhile, as the electrochemists are naturally focusing on the WE, the counter electrode (CE) in electrochemical systems is often neglected as it just serves to flow currents generated at WE while maintaining the reference electrode in its fully potentiometric mode. Opening an electrochemistry textbook [3-5], all the theories and analysis are built around the WE, and the $\mathrm{CE}$ is supposed not to interfere the working electrode by having sufficiently large active area, distance from working electrode, low polarization, homogeneous current distribution, etc. On the other hand, $\mathrm{CE}$ is an indispensable part of an electrochemical system even for the simplest two-electrode configurations [36,37]. As current flows through it, non-Faradaic or Faradaic processes always occur at CE interface with the electrolyte. In some circumstances, people take this advantage to transform currents into a fluorescence signal [38]. Moreover, interdigitated electrodes may increase the current response in amperometric analysis due to the redox cycle where the reactant for WE reactions is regenerated on the CE by the reversed reaction $[39,40]$. In electrochromic devices, $\mathrm{CE}$ is sometimes also modified with an electrochromic material that has the same colour change as WE but under opposite polarization [41]. However, CE clearly attracts much less attention as compared with WE, especially in electrochemical analysis where the current is usually very low.

Here, we attempt to carry out electrochemical stripping analysis not based on directly preconcentrating the analyte on WE, but indirectly extracting signals from $\mathrm{CE}$. The concept is illustrated in Scheme 1. The electrochemical cell 1 consists of two compartments, which are denoted as Cell 1a and Cell 1b. The WE1 and the reference electrode (RE1) are placed in Cell 1a, whereas the CE1 is placed in Cell 1b. The two compartments are connected with a "bridge", which can be a salt bridge as in classical voltaic cells, or an electron conductor such as metal wire or plate. In the former case, compartments $1 \mathrm{a}$ and $1 \mathrm{~b}$ are half-cells, while in the latter case they are independent electrochemical cells connected in series. The latter is often used as closed bipolar system for studying the reactions at the "bridge" [38, 42, 43], but here we focus on the 
reactions on WE1 and CE1 (denoted as source electrodes in bipolar systems [44]) instead. A model analyte $\left(\mathrm{Fc}(\mathrm{MeOH})_{2}\right)$ is added in Cell 1a, with the model metal ion $\mathrm{Cu}^{2+}$ in Cell $1 \mathrm{~b}$. By oxidizing the analyte on WE1 during the measurement, $\mathrm{Cu}^{2+}$ may be simultaneously reduced on CE1. The corresponding reactions are: at WE1: $\mathrm{Fc}(\mathrm{MeOH})_{2}-1 \mathrm{e}^{-} \rightarrow\left[\mathrm{Fc}(\mathrm{MeOH})_{2}\right]^{+}$

$$
\text { at } \mathrm{CE} 1: \mathrm{Cu}^{2+}+2 \mathrm{e}^{-} \rightarrow \mathrm{Cu}^{(0)}
$$

Consequently, the CE1 is taken out from Cell $1 \mathrm{~b}$, cleaned, and transferred to another electrochemical cell (Cell 2) for stripping analysis of $\mathrm{Cu}$ :

$$
\text { at WE2 (i.e., CE1 coming from cell 1): } \mathrm{Cu}^{(0)}-2 \mathrm{e}^{-} \rightarrow \mathrm{Cu}^{2+}
$$

Cell 2 is a classical three-electrode cell, with CE1 connected as WE2, and another pair of RE2 and CE2. The solution in Cell 2 only contains supporting electrolyte, with the $\mathrm{pH}$ adjusted to be favourable for $\mathrm{Cu}$ stripping. In this way, the charge corresponding to the oxidation of the analyte on WE1, which is related to the analyte concentration, is linked to the charge of $\mathrm{Cu}$ deposition on CE1. The latter can be analyzed by the stripping signals from Cell 2. Thus, the concentration of analyte can be indirectly determined by analysing the stripping signals from the CE. Like in classical stripping analysis, by increasing the oxidation of analyte on WE1, the charge of $\mathrm{Cu}$ deposition on $\mathrm{CE} 1$ is also expected to increase, leading to an increase in the stripping signal intensity which may improve the sensitivity of the analysis. This work explores a new access to electrochemical analysis through signals from $\mathrm{CE}$, which may extend the applications of stripping to analytes that do not deposit or adsorb on the WE.

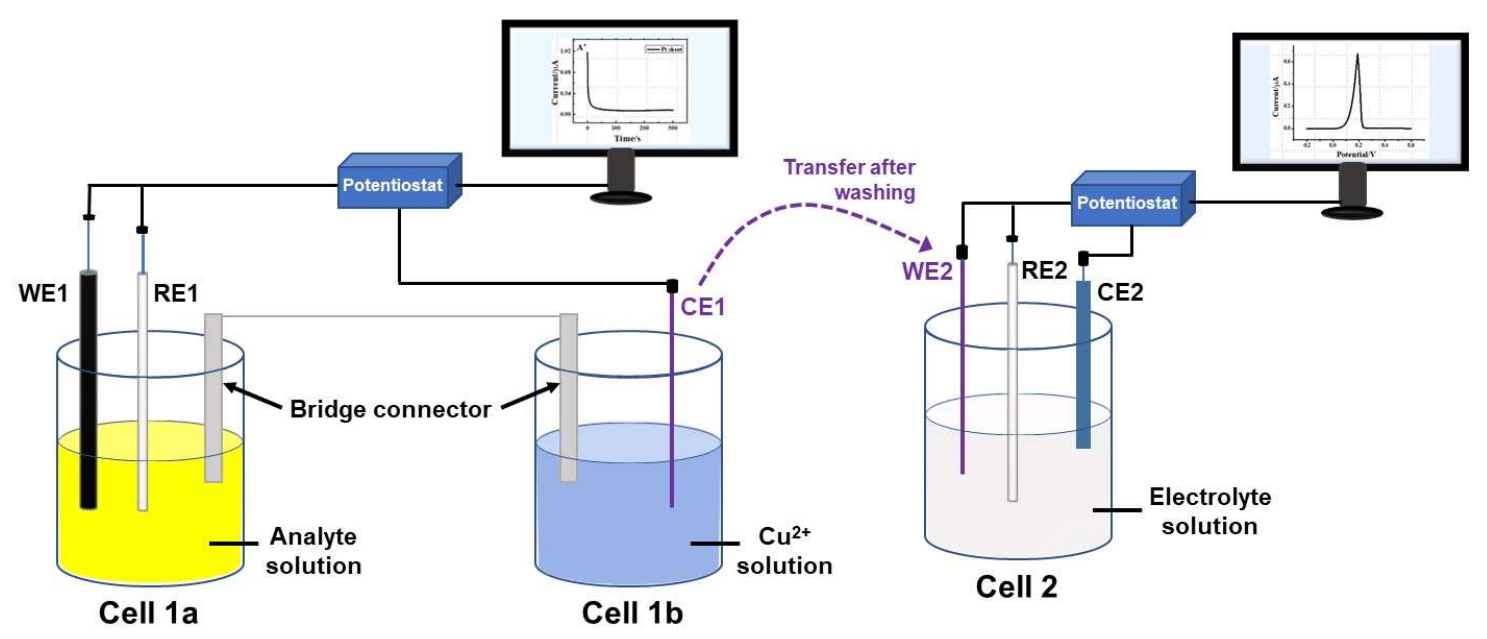

Scheme 1. (A) Schematic diagram illustrating the indirect detection of $\mathrm{Fc}(\mathrm{MeOH})_{2}$, via copper deposition and stripping in two separate setups, with cells composition as follow. Cell1a: various concentrations of $\mathrm{Fc}(\mathrm{MeOH})_{2}+0.1 \mathrm{M} \mathrm{NaNO}_{3}(\mathrm{pH}=5.58)$; Cell1b: $0.2 \mathrm{M} \mathrm{CuSO}_{4}+0.1 \mathrm{M}$ $\mathrm{NaNO}_{3}(\mathrm{pH}=2)$; Cell2: $0.1 \mathrm{M} \mathrm{NaNO} 3(\mathrm{pH}=2)$. WE1: glassy carbon electrode (GCE); RE1 and $\mathrm{RE}$ 2: $\mathrm{Ag} / \mathrm{AgCl}$ reference electrodes; $\mathrm{CE} 1$ : $\mathrm{Pt}$ microelectrode (transferred to Cell 2 and connected as WE2 for anodic stripping); CE2: Pt sheet. 


\section{Experimental}

\subsection{The electrochemical cell configuration}

The electrochemical cell configuration is shown in Scheme 1. In a first compartment (Cell 1a), a glassy carbon electrode of $3 \mathrm{~mm}$ diameter (CHI 104) was connected as WE1, and a commercial $\mathrm{Ag} / \mathrm{AgCl}(1 \mathrm{M} \mathrm{KCl}) \mathrm{RE}$ (CHI 111) was connected as $\mathrm{RE} 1$. In the second compartment (Cell 1b), platinum electrodes of different size were used as CE1, including Pt sheet ( $2 \mathrm{~mm} \times 0.5 \mathrm{~mm}$, ChemPur, Germany), Pt disk electrode of $2 \mathrm{~mm}$ diameter (CHI 102), and Pt micro-disk electrode of $25 \mu \mathrm{m}$ diameter (preparation detailed in Supporting Information). Several types of "bridge" between Cells 1a and 1b were studied: (1) ionic salt bridge prepared by agar and saturated potassium chloride solution filled in a glass U-tube; (2) Pt sheets of $0.5 \mathrm{~cm}$ width and 1 or $2 \mathrm{~cm}$ immersed length; (3) $\mathrm{Cu}$ wire of $0.5 \mathrm{~mm}$ diameter and $2.5 \mathrm{~cm}$ immersed length. Cell 1a consists of various concentrations of $\mathrm{Fc}(\mathrm{MeOH})_{2}$ (from 0 as blank to $10 \mu \mathrm{M}$ ) and $0.1 \mathrm{M} \mathrm{NaNO}_{3}$ as supporting electrolyte, without any added buffer ( $\mathrm{pH}$ measured around 5.8). Cell $1 \mathrm{~b}$ consists of selected concentrations of $\mathrm{CuSO}_{4}(0.002,0.02,0.2$ and $2 \mathrm{M}$ ) in $0.1 \mathrm{M} \mathrm{NaNO}_{3}$, with $\mathrm{pH}$ adjusted to 2 (using $\mathrm{HNO}_{3}$ ). In Cell 2, a separate pair of $\mathrm{Ag} / \mathrm{AgCl} \mathrm{RE}$ and Pt sheet $(2 \mathrm{~mm} \times 0.5 \mathrm{~mm}$, ChemPur, Germany) were connected as RE2 and CE2, respectively, whereas WE2 was the CE1 electrode transferred from Cell $1 \mathrm{~b}$ after washing. The solution in Cell 2 is free of $\mathrm{Cu}^{2+}$ but with the same electrolyte and $\mathrm{pH}$ as in Cell $1 \mathrm{~b}(0.1 \mathrm{M}$ $\mathrm{NaNO}_{3}, \mathrm{pH}$ 2). Note that both the classical three-electrode cell and the two separate compartments connected with either salt or metallic bridges gave exactly the same voltammetric signals (Figure S1). This indicates that the potentiostat functions normally under the experimental conditions.

\subsection{The protocol of analysis}

All electrochemical experiments were carried out on a PalmSens 4 potentiostat (PalmSens, Netherland). Before each measurement, CE1 was polished with $0.3 \mu \mathrm{m}$ abrasive discs (Buehler, USA), and both WE1 and CE1 were then polished with $0.05 \mu \mathrm{m}$ alumina paste on cloth. The electrodes were sonicated in water, EtOH and water consecutively. This procedure ensured thorough regeneration of both WE1 and CE1 before quantitative analysis. The first step of measurement was connecting Cell 1 for the oxidation of $\mathrm{Fc}(\mathrm{MeOH})_{2}$. Linear scan voltammetry (LSV) or chronoamperometry (CA) were performed, respectively by scanning potentials (from -0.2 to $0.6 \mathrm{~V}$ at $50 \mathrm{mV} / \mathrm{s})$ or applying a constant potential $(+0.3 \mathrm{~V}$, typically for $300 \mathrm{~s}$ if not stated otherwise) at WE1. The current response as well as the cell voltage between WE1 and 
CE1 were recorded. Afterwards, the electrodes were disconnected, and CE1 was removed from Cell 1b, thoroughly rinsed with water and transferred to Cell 2. It was then connected as WE2, along with RE2 and CE2. The stripping analysis was performed by scanning the potential of WE2 from -0.2 to $0.6 \mathrm{~V}(v s . \mathrm{Ag} / \mathrm{AgCl})$ at a scan rate of $50 \mathrm{mV} / \mathrm{s}$. Most of the stripping experiments were carried out by LSV, while differential pulse voltammetry (DPV) was also applied in attempting to increase the sensitivity of the method. After each series of measurement, WE2 and WE1 were regenerated by polishing and sonication for the next one as described above. As each cell contains a different solution, we recommend to minimize crosscontamination by transferring only CE1/WE2 while keeping all other electrodes separate and always in their own cells.

\section{Results and Discussion}

\subsection{Proof-of-concept: Establishment of the method}

As the concept is based on analyzing signals from CE, its choice is the first step to explore. Three Pt electrodes of different size are tested as CE1 for carrying out the same LSV analysis of $\mathrm{Fc}(\mathrm{MeOH})_{2}$ in Cell 1: a Pt sheet of much larger area than WE1, a Pt disk electrode of comparable area as WE1, and Pt microelectrode of much smaller area than WE1. Figure 1A shows the current response as a function of scanning potential using the system made of the two compartments $1 \mathrm{a} \& 1 \mathrm{~b}$. The voltammogram is similar as that measured from classical threeelectrode single cell, showing an oxidation peak for $\mathrm{Fc}(\mathrm{MeOH})_{2}$ at $c a .+0.22 \mathrm{~V}(v s . \mathrm{Ag} / \mathrm{AgCl})$. The current recorded with different CE1 almost overlap, indicating that the size of CE does not change neither the peak potential not its intensity under these experimental conditions. During the measurement, the cell voltage, that is, the potential $E_{W E 1} v S . E_{C E 1}$, is also monitored, as shown in Figure 1B. Here, a clear difference is seen from different CE1. For the macroscopic Pt sheet and Pt disk, the cell voltage changes almost linearly as the potential of WE1 is scanned from -0.2 to $+0.6 \mathrm{~V}$ (vs. $\mathrm{Ag} / \mathrm{AgCl}$ ). The slope as a function of time is almost the same as the scan rate of $E_{W E 1}$. This suggests that the potential drop at the bridge (two electrochemical interfaces with the solutions in Cell 1a and 1b) and CE1 is stable, which fulfils the criteria for selecting CE [45]. However, when a Pt microelectrode is used as CE1, the cell voltage rapidly varies from -2.0 to $0 \mathrm{~V}$ in the first $1 \mathrm{~s}$, and then slightly increases to $c a .0 .8 \mathrm{~V}$ with similar slope as $E_{W E 1}$. With the same current flowing through CE1 as seen from Figure 1A, the current density on Pt microelectrode is much higher than that on Pt sheet or disk. This leads to the polarization of the electrode and may explain the phenomenon. As the potential of $E_{W E I}$ is controlled, the more positive $E_{W E 1} v s$. $E_{C E 1}$ qualitatively suggests that the potential of $E_{C E 1}$ is 
more negative, which drives the reduction of $\mathrm{Cu}^{2+}$ in $\mathrm{Cell} 1 \mathrm{~b}$ to form $\mathrm{Cu}^{(0)}$ deposit on CE1. This is examined by transferring CE1 to Cell 2 (as WE2) for anodic stripping. Figure 1C shows a clear stripping peak of $\mathrm{Cu}^{(0)}$ at $c a .0 .18 \mathrm{~V}$ (vs. $\mathrm{Ag} / \mathrm{Cl}$ ) for Pt microelectrode, which cannot be detected when using Pt sheet and disk electrodes (see inset). The deposition of $\mathrm{Cu}$ on micro-Pt CE1 is further confirmed with optical microscopy observation (Figure S2). This suggests the possibility to capture potentially useful signals from microelectrode $\mathrm{CE}$, supporting the feasibility of the concept. Note that the quantitative analysis of the potential $E_{C E I} v s . E_{R E I}$ would be difficult due to the two electrochemical interfaces of the "bridge" with the solutions in Cell $1 \mathrm{a}$ and $1 \mathrm{~b}$.
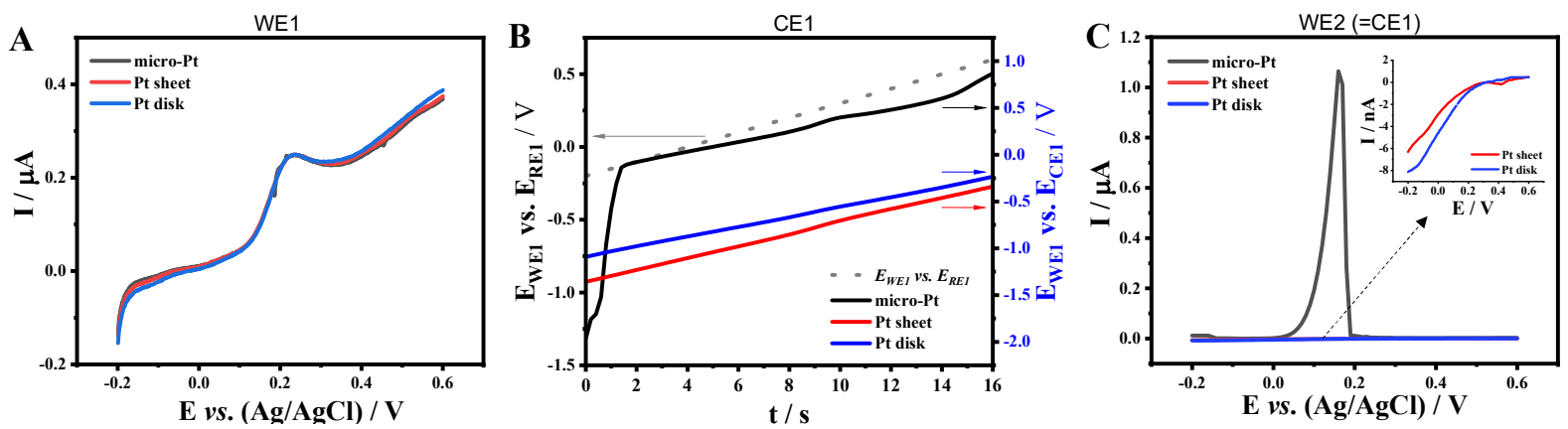

Figure 1. Linear sweep voltammetry in Cell 1 with $\mathrm{GCE}$ as $\mathrm{WE} 1, \mathrm{Ag} / \mathrm{AgCl}$ as $\mathrm{RE} 1$, and $\mathrm{Pt}$ sheet, disk or microelectrode as CE1: (A) current response at WE1; (B) variation of cell voltage with time. Solution in Cell 1a: $10 \mu \mathrm{M} \mathrm{Fc}(\mathrm{MeOH})_{2}+0.1 \mathrm{M} \mathrm{NaNO}_{3}(\mathrm{pH} 5.8)$; solution in Cell 1b: $0.2 \mathrm{M} \mathrm{CuSO}_{4}+0.1 \mathrm{M} \mathrm{NaNO}_{3}(\mathrm{pH} \mathrm{2}$ ); "bridge": $\mathrm{Cu}$ wire; scan rate: $50 \mathrm{mV} / \mathrm{s}$. (C) Anodic stripping voltammetry of CE1 transferred as WE2 in Cell 2. Solution: $0.1 \mathrm{M} \mathrm{NaNO}_{3}(\mathrm{pH} 2)$; scan rate: $50 \mathrm{mV} / \mathrm{s}$. Inset graph: enlarged views of current at Pt sheet and disk electrodes.

After choosing micro-Pt as the most suitable CE1 electrode, the next step is to investigate the measurement method for quantification. Figure $2 \mathrm{~A}$ compares the LSV of $10 \mu \mathrm{M} \mathrm{Fc}(\mathrm{MeOH})_{2}$ with that of the blank solution (i.e., electrolyte without $\left.\mathrm{Fc}(\mathrm{MeOH})_{2}\right)$ in Cell 1a. It is seen that the oxidation peak may clearly differentiate the two solutions, with evidently no peak observed in the absence of the redox probe. Nevertheless, in both solutions $\mathrm{Cu}^{(0)}$ deposition is occurring on CE1 as evidenced by stripping peaks recorded in Cell 2, yet with higher current in $\mathrm{Fc}(\mathrm{MeOH})_{2}$ solution than in the blank (Figure 2B). The quantity of $\mathrm{Cu}^{(0)}$ deposited on $\mathrm{CE} 1$ is slightly more than two times larger (as seen from the stripping current/charge in Cell 2) when $\mathrm{Fc}(\mathrm{MeOH})_{2}$ is present in Cell 1a, further confirming the feasibility for indirect analysis, yet still unfavourable for quantification due to the presence of quite high signal from the analytefree blank solution. This is because the deposition of $\mathrm{Cu}^{(0)}$ on $\mathrm{CE} 1$ is affected by the 
polarization, which depends on the current flow through the cell (WE1 and CE1) but cannot differentiate the nature of the current (Faradic and residual/capacitive) [46]. That is to say, as long as the potential of CE1 allows, both non-Faradaic and Faradaic current for WE1 may contribute to $\mathrm{Cu}^{(0)}$ deposition on CE1. In LSV, non-Faradaic current is always present due to the scanning potential, thus it may complicate the quantification analysis from CE1 stripping signals. Therefore, chronoamperometry (CA) is used to reduce the interference of non-Faradaic current by fixing the potential applied on WE1 at a value enabling the oxidation of the probe. Figure 2C shows the current variation with time by applying a potential of $+0.3 \mathrm{~V}$ ( $v s$. $\mathrm{Ag} / \mathrm{AgCl})$. The current also consists of non-Faradaic and Faradaic components but the former, $I_{n F}$, depending on the solution resistance and the double-layer capacitance of the electrode, decreases rapidly with time $(E q .1)$ [3].

$$
I_{n F}(t)=\frac{E}{R_{s}} e^{\left(-t / R_{s} C_{d l}\right)}
$$

with $R_{s}$ the solution resistance and $C_{d l}$ the double layer capacitance. Normally, the range $R_{s}$ is 10-100 $\Omega$ and $C_{d l}$ is $10-100 \mu \mathrm{F}$, so that the double layer charging current becomes negligible rapidly after applying the potential step ( $c a$. after $50 \mathrm{~ms}$ ), which is much less than the time window of the experiments performed here. Therefore, the charge flowing through the Cell 1 mainly depends on the Faradaic current, $I_{F}$, which in this case approximately follows Cottrell equation (Eq. 2) [3] and it is proportional to the concentration of the analyte $\mathrm{Fc}(\mathrm{MeOH})_{2}$ and to the inverse of square root of time.

$$
I_{F}(t)=\frac{n F A D^{1 / 2} C}{(\pi t)^{1 / 2}}
$$

with $n$ the number of exchanged electrons, $F$ the Faraday constant, A the electrode surface area, $D$ the diffusion coefficient of the probe and $C$ its concentration in solution.

It means that $I_{F}$ still keeps $10 \%$ of its value when passing from 1 to $100 \mathrm{~s}$ of CA experiment. Note that when the concentration of $\mathrm{Fc}(\mathrm{MeOH})_{2}$ near WE1 is very low due to the diffusion limit, the kinetics of its oxidation cannot be negligible. This may explain the current "plateau" at a very low value (order of magnitude lower than the initial current) instead of decreasing to zero. Nevertheless, the kinetics also depend on the concentration of $\mathrm{Fc}(\mathrm{MeOH})_{2}$ thus the linear relationship between Faradaic current and $\mathrm{Fc}(\mathrm{MeOH})_{2}$ concentration is still valid. It also explains the higher current "plateau" for $\mathrm{Fc}(\mathrm{MeOH})_{2}$ solution as compared with that for the blank one. As a consequence, the quantity of $\mathrm{Cu}^{(0)}$ deposited on $\mathrm{CE} 1$ is also much higher after measurement in $\mathrm{Fc}(\mathrm{MeOH})_{2}$ than in the blank solution, as seen from the stripping signal in Cell 
2 (Figure 2D). It is interesting to see that $\mathrm{Cu}^{(0)}$ deposition is invisible after chronoamperometry in the blank solution, even though the current is not zero due to the non-Faradaic contribution. This is perhaps due to the charging of CE1 that compensates (at least partially) the non-Faradaic charge on WE1. Although the area of CE1 is much smaller than that of WE1, the potential step induced by the flown current can be much steeper thus the non-Faradaic charge may also not be negligible. From the analytical point of view, Figure 2D eliminates the blank signal as compared with Figure 2B. It also offers more significant difference in $\mathrm{Cu}^{(0)}$ deposition charge for analysing the same concentration of $\mathrm{Fc}(\mathrm{MeOH})_{2}$ (Figure S3). Thus, chronoamperometry is more preferable and was chosen for further quantitative analysis.
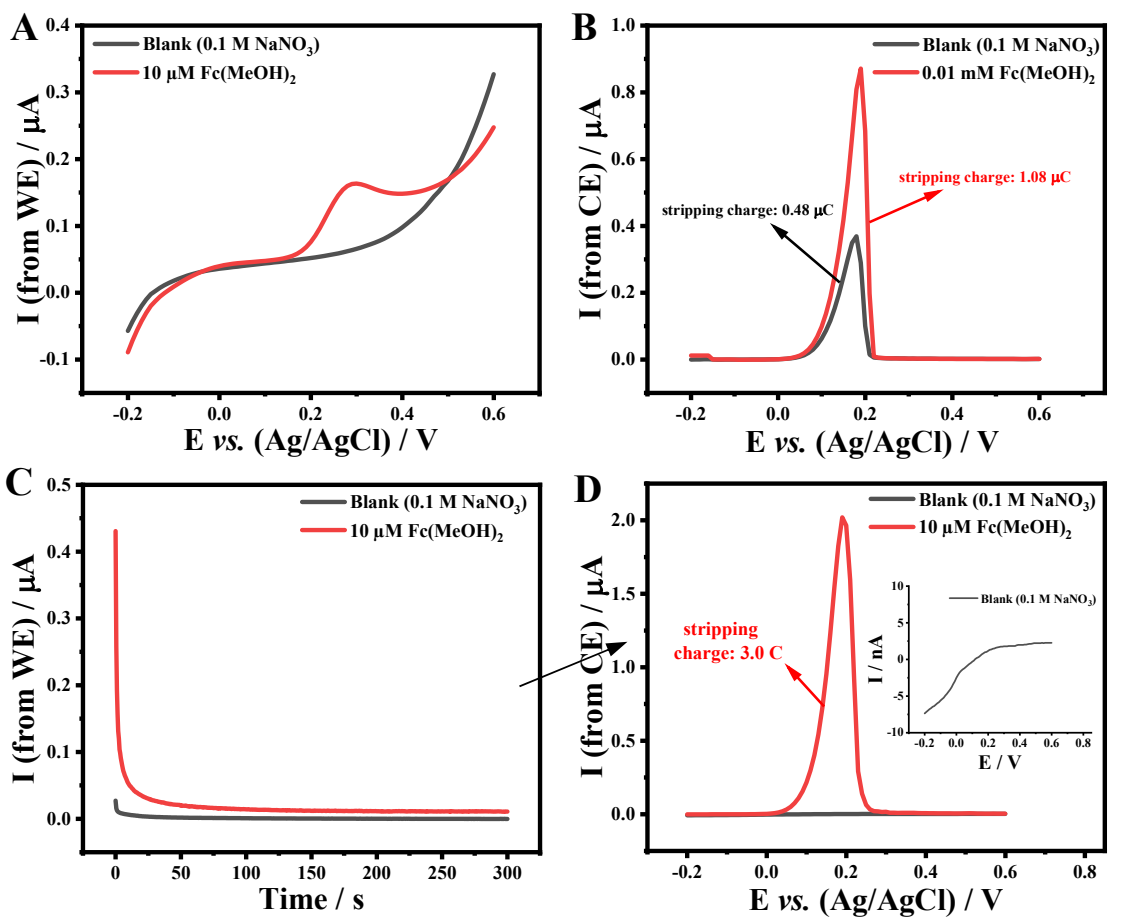

Figure 2. (A) LSV of GCE in $10 \mu \mathrm{M} \mathrm{Fc}(\mathrm{MeOH})_{2}$ (red line) and the blank solution (black line) in Cell 1a; (B) Corresponding anodic stripping of $\mathrm{Cu}^{(0)}$ deposited on CE1, as measured by LSV in Cell 2 after treatment as in (A); (C) chronoamperometry of GCE in $10 \mu \mathrm{M} \mathrm{Fc}(\mathrm{MeOH})_{2}$ (red line) and the blank solution (black line) in Cell la at an applied potential of $+0.3 \mathrm{~V}$ ( $v s$. $\mathrm{Ag} / \mathrm{AgCl}$ ); (D) Corresponding anodic stripping of $\mathrm{Cu}^{(0)}$ deposited on $\mathrm{CE} 1$ after treatment as in (C). Scan rate in (A), (B) and (D): $50 \mathrm{mV} / \mathrm{s} ; \mathrm{Cu}^{2+}$ concentration in Cell $1 \mathrm{~b}: 0.02 \mathrm{M}$; "bridge" connector: copper wire.

\subsection{Factors affecting the analysis}

Based on the results above, one can conclude that chronoamperometry is suitable for the stripping analysis of non-adsorbing $\mathrm{Fc}(\mathrm{MeOH})_{2}$ model analyte, indirectly from the stripping of 
$\mathrm{Cu}^{(0)}$ on the $\mathrm{CE}$. To gain more insights into the analytical process, various factors that may affect the signals were systematically studied. These include the electrolysis duration and the potential applied on WE1 in Cell 1a, the $\mathrm{Cu}^{2+}$ concentration and $\mathrm{pH}$ of the solution in Cell $1 \mathrm{~b}$, as well as the type of "bridge" connector.

A first parameter likely to influence the electrode response is the time afforded for the oxidation of the probe. Like in classical stripping voltammetry where the analyte is pre-concentrated on the working electrode by deposition for a period of time for enhancing the signals, the chronoamperometry on WE1 may also offer a possibility to increase the amount of $\mathrm{Cu}^{(0)}$ deposited on CE1 by prolonging $\mathrm{CA}$ in Cell 1 and consequently increase the stripping signal measured from Cell 2. Figure 3A shows the charge integrated from CA curves at increasing electrolysis times for blank and analyte solutions. It is seen that the charge increases with time for all the solutions, yet being more intense for those containing the $\mathrm{Fc}(\mathrm{MeOH})_{2}$ probe, which agrees with the non-zero current in the measurements. In contrary, the variation of charge corresponding to the stripping of deposited $\mathrm{Cu}^{(0)}$, as measured in Cell 2, shows a different behaviour (Figure 3B). For the blank solution, no $\mathrm{Cu}^{(0)}$ is detected even by extending the $\mathrm{CA}$ duration time to $1000 \mathrm{~s}$. This suggests that the low residual current in blank solution may not be sufficient to polarize CE1 to a potential favourable for $\mathrm{Cu}^{2+}$ reduction. It is ideal from the analytical aspect to have a zero blank signal. For $10 \mu \mathrm{M} \mathrm{Fc}(\mathrm{MeOH})_{2}$ solution, the $\mathrm{Cu}^{(0)}$ stripping charge increases as the potential is applied on WE1 for longer time, which is consistent with the oxidation of more $\mathrm{Fc}(\mathrm{MeOH})_{2}$ on WE1 and concomitant $\mathrm{Cu}^{2+}$ reduction on $\mathrm{CE} 1$, similarly as in classical stripping analysis. However, when the $\mathrm{Fc}(\mathrm{MeOH})_{2}$ concentration is $50 \mu \mathrm{M}$, the $\mathrm{Cu}^{(0)}$ stripping charge increases with time only up to $600 \mathrm{~s}$, and then decreases even though the integrated charge from CA continues to increase (compare blue curves in Figure 3). One possible explanation for this phenomenon is that the Pt micro-counter electrode is too small to carry large amounts of deposited $\mathrm{Cu}^{(0)}$, so the excess of deposit might partially peel off from CE1 leading to the decrease in stripping charge of WE2. This is also supported by the shape of stripping curves that show multiple peaks of $\mathrm{Cu}^{(0)}$ oxidation (an indication of multi-layer deposition, Figure S4). Overall, the above results suggest that extending time may enhance the charge of $\mathrm{Cu}^{(0)}$ stripping on WE2 for measuring low concentrations of analyte in Cell 1a, while it is unfavourable in the case of too high analyte concentrations due to excess deposition. The latter could potentially be solved by using CE1 of larger area. Nevertheless, as the analytical interest is naturally on low concentration, this is not further explored in this work. The relationship between time, $\mathrm{Fc}(\mathrm{MeOH})_{2}$ concentration and copper deposition charge, paves 
the way for indirectly "stripping" $\mathrm{Fc}(\mathrm{MeOH})_{2}$ from the $\mathrm{CE}$, and constitutes the basis for further quantitative analysis.
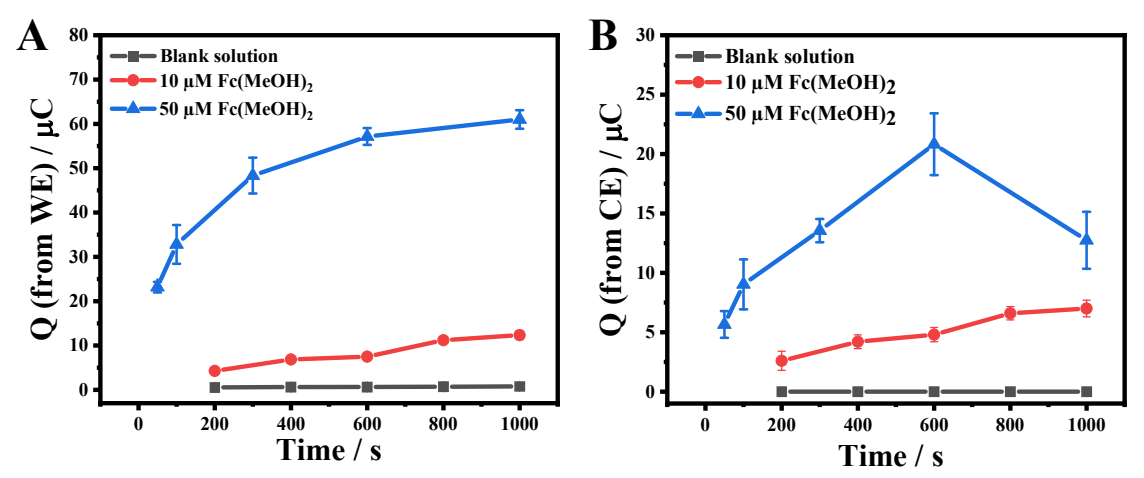

Figure 3. Variation of charge as a function of CA duration (by applying $+0.3 \mathrm{~V}$ to WE1 for various times in blank or 10 and $50 \mu \mathrm{M} \mathrm{Fc}(\mathrm{MeOH})_{2}$ solutions in Cell 1a), respectively, measured from integration of (A) CA currents recorded at WE1 in Cell 1 or (B) stripping signals obtained with WE2 $(=\mathrm{CE} 1)$ in Cell 2 . Error bars indicate the standard deviation of 5 repetitive measurements.

Figures 4 and S5 show the effect of applied potential on the signals from WE1 and the WE2 $(=\mathrm{CE} 1)$. It is seen from Figure 4A that the charge integrated from current response in Cell 1 increases with applied potential for both blank and $30 \mu \mathrm{M} \mathrm{Fc}(\mathrm{MeOH})_{2}$ solutions. The charge measured in the presence of $\mathrm{Fc}(\mathrm{MeOH})_{2}$ is higher than that measured from the blank, which is evidently due to the Faradaic contribution from the oxidation of the redox probe. Moreover, the increase in charge tends to level off above $+0.3 \mathrm{~V}$, a value approaching the formal redox potential of $\mathrm{Fc}(\mathrm{MeOH})_{2}$. At high potential, the oxidation current is limited by diffusion, which tends to be independent of potential when the surface concentration of $\mathrm{Fc}(\mathrm{MeOH})_{2}$ is zero. In reality, a slight increase in current and charge is still observed when the potential increases beyond $+0.3 \mathrm{~V}$ (Figure S5B), as a result of slightly faster electron transfer kinetics at larger overpotentials. Figure 4B shows the variation of the charge corresponding to the deposited $\mathrm{Cu}^{(0)}$ on $\mathrm{CE} 1$, which is measured from stripping of WE2 in Cell 2. In the presence of $\mathrm{Fc}(\mathrm{MeOH})_{2}$, the general trend is similar to Figure $\mathbf{4 A}$, confirming that the charge of $\mathrm{Cu}^{(0)}$ stripping is correlated with the oxidation of the probe on WE1. At larger overpotentials, excess deposition of $\mathrm{Cu}$ is seen from multiple peaks in stripping (Figure S5D). It should be noted that for the blank solution, if copper deposition is not detectable when the potential is up to $+0.3 \mathrm{~V}$ (consistent with above data (Figure 3) suggesting that stripping signal from counter-electrode may shield part of the blank signals), this is no more true when the potential increases beyond $+0.3 \mathrm{~V}$ for which the blank solution also yields a visible $\mathrm{Cu}^{(0)}$ stripping signal (due to greater 
polarization of the electrode),. Therefore, we consider $+0.3 \mathrm{~V} v s . \mathrm{Ag} / \mathrm{AgCl}$ as an optimal potential for the indirect determination of $\mathrm{Fc}(\mathrm{MeOH})_{2}$ by stripping.
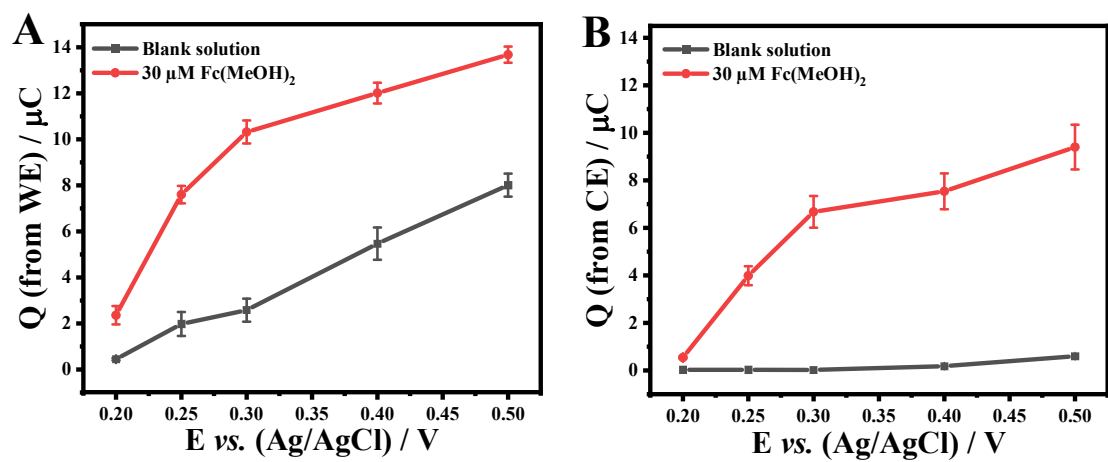

Figure 4. Effect of the potential applied to WE1 for $300 \mathrm{~s}$ in blank and $30 \mu \mathrm{M} \mathrm{Fc}(\mathrm{MeOH})_{2}$ solutions in Cell 1a, on the charges measured from integration of (A) CA currents recorded at WE1 in Cell 1 or (B) stripping signals obtained with WE2 (= CE1) in Cell 2. Error bars indicate the standard deviation of 5 repetitive measurements.

As the analysis is carried out indirectly from the signals obtained from CE1 (=WE2), the whole part of Cell $1 \mathrm{~b}$ can be regarded as the sensing element. That being said, apart from the selection of CE (shown in Figure 1), the solution in Cell $1 \mathrm{~b}$ is also likely to play an important role. As the stripping signals measured from WE2 in Cell 2 arise from copper reduction/deposition on $\mathrm{CE} 1$, the concentration of $\mathrm{Cu}^{2+}$ in Cell $1 \mathrm{~b}$ would affect the deposition process and thus influence the whole analysis. Figure 5A shows that the charge from CA current integration almost keeps unchanged with $\mathrm{Cu}^{2+}$ concentration in Cell $1 \mathrm{~b}$ by applying $+0.3 \mathrm{~V} v$ s. $\mathrm{Ag} / \mathrm{AgCl}$ for $300 \mathrm{~s}$ on WE1 for any fixed $\mathrm{Fc}(\mathrm{MeOH})_{2}$ concentration in Cell 1a. This is not really surprising as the composition of the compartment $1 \mathrm{~b}$ comprising the counter-electrode is not expected to affect the response of WE1 in Cell 1a. The only variation of charge is that with increasing $\mathrm{Fc}(\mathrm{MeOH})_{2}$ concentration, as expected by the oxidation of larger amounts $\mathrm{Fc}(\mathrm{MeOH})_{2}$ (in agreement with the trend from previous figures). Nevertheless, with the same charge passing through WE1 and $\mathrm{CE} 1$, the amount of $\mathrm{Cu}^{(0)}$ deposited on CE1 is different when the concentration of $\mathrm{Cu}^{2+}$ in Cell $1 \mathrm{~b}$ differs, as shown in Figure 5B. A general trend is that the $\mathrm{Cu}^{(0)}$ stripping charge first increases and then decreases as the $\mathrm{Cu}^{2+}$ concentration in Cell $1 \mathrm{~b}$ increases. With $0.002 \mathrm{M} \mathrm{Cu}^{2+}$ in Cell $1 \mathrm{~b}$, the deposition is likely diffusion-controlled as the solution is not stirred during the analysis. As a result, the deposition of $\mathrm{Cu}^{(0)}$ is limited. This may also explain that at so low $\mathrm{Cu}^{2+}$ concentration in Cell $1 \mathrm{~b}$, different concentration of $\mathrm{Fc}(\mathrm{MeOH})_{2}$ in Cell 1a results in almost insignificant difference in the $\mathrm{Cu}^{(0)}$ stripping charge (Figure 5B) even though the charge flowing through Cell 1 significantly increases (Figure 
5A). When $\mathrm{Cu}^{2+}$ concentration is in the range of 0.02 to $0.2 \mathrm{M}$, the kinetic contribution to $\mathrm{Cu}^{(0)}$ deposition is dominant, thus the amount of reduced copper increases and becomes more dependent on the current or charge flowing through Cell 1 . This notably affects the signals for relatively high concentration $(30 \mu \mathrm{M})$ of $\mathrm{Fc}(\mathrm{MeOH})_{2}$. However, when the Cell $1 \mathrm{~b}$ contains $2 \mathrm{M}$ $\mathrm{Cu}^{2+}$, the charge measured from stripping decreases for all the three solutions of distinct $\mathrm{Fc}(\mathrm{MeOH})_{2}$ concentration (with copper deposits less visible from optical microscopy, Figure S6), the reason for this phenomenon remaining unclear. From results of Figure 5, one can conclude that the $\mathrm{Cu}^{2+}$ concentration in Cell $1 \mathrm{~b}$ may influence the stripping charge for analyzing the same $\mathrm{Fc}(\mathrm{MeOH})_{2}$ solution under the same conditions, and that values in the range of 0.02 to $0.2 \mathrm{M} \mathrm{Cu}^{2+}$ would be the most suitable for quantitative analysis.
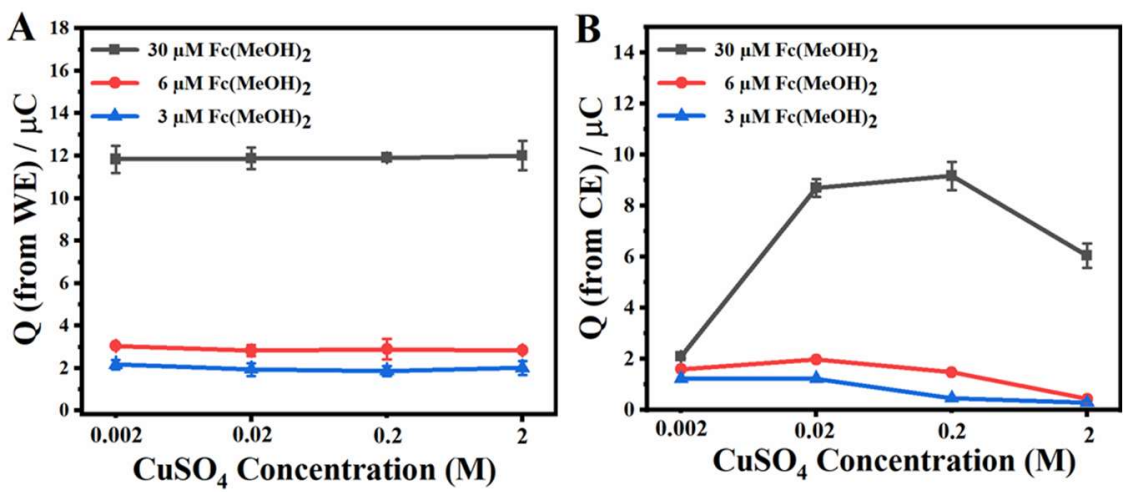

Figure 5. Effect of $\mathrm{Cu}^{2+}$ concentration in Cell $1 \mathrm{~b}$, on the charges measured from integration of (A) CA currents recorded at WE1 in Cell 1 or (B) stripping signals obtained with WE2 (= CE1) in Cell 2. The data correspond to CA experiments performed by applying $+0.3 \mathrm{~V}(v s . \mathrm{Ag} / \mathrm{AgCl})$ to WE1 for $300 \mathrm{~s}$, in solutions containing 3, 6 or $30 \mu \mathrm{M} \mathrm{Fc}(\mathrm{MeOH})_{2}$ in Cell 1a. Error bars indicate the standard deviation of 5 repetitive measurements. The $\mathrm{Cu}^{2+}$ concentration axis is in logarithmic scale.

Besides $\mathrm{Cu}^{2+}$ concentration, $\mathrm{pH}$ of the solution in Cell $1 \mathrm{~b}$ may also influence the measurement. Figure 6 compares the charge measured from integrating the current on WE1 and that from $\mathrm{Cu}^{(0)}$ stripping on $\mathrm{CE} 1$ (=WE2), for the analysis of $10 \mu \mathrm{M} \mathrm{Fc}(\mathrm{MeOH})_{2}$ in Cell 1a, and using $0.2 \mathrm{M} \mathrm{Cu}^{2+}$ at various $\mathrm{pH}$ in Cell $1 \mathrm{~b}$. It is clearly seen that the charge from current integration on WE1 almost keeps constant. This agrees with previous results (Figure 5A), indicating that the composition of Cell $1 \mathrm{~b}$ does not affect the current measurement during oxidation of $\mathrm{Fc}(\mathrm{MeOH})_{2}$. The charge calculated from $\mathrm{Cu}^{(0)}$ stripping is always lower than that measured from current integration on WE1, which can be attributed to $\mathrm{H}_{2}$ evolution (a competing reaction for $\mathrm{Cu}^{2+}$ reduction under cathodic polarization of $\mathrm{CE} 1$ ). This is especially significant at $\mathrm{pH} 1$ while the $\mathrm{H}_{2}$ evolution effect is less pronounced at $\mathrm{pH} 2$, leading to an increase in the $\mathrm{Cu}^{(0)}$ stripping charge. In less acidic solutions, especially at $\mathrm{pH} 4$, the reduction of $\mathrm{Cu}^{2+}$ may get 
complicated by forming intermediates containing $\mathrm{Cu}^{(\mathrm{I})}$ species. The stripping signal is also less clean with multiple peaks (Figure S7), which is not favourable for quantification.

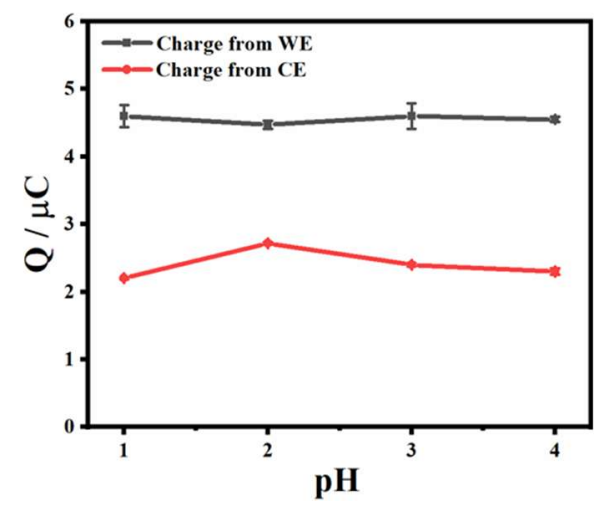

Figure 6. Effect of $\mathrm{pH}$ of the $\mathrm{Cu}^{2+}$ solution $(0.2 \mathrm{M})$ in Cell $1 \mathrm{~b}$, on the charges measured from integration of CA currents recorded at WE1 in Cell 1 (black) or stripping signals obtained with WE2 (=CE1) in Cell 2 (red). The data correspond to CA experiments performed by applying $+0.3 \mathrm{~V}(v s . \mathrm{Ag} / \mathrm{AgCl})$ to $\mathrm{WE} 1$ for $300 \mathrm{~s}$, in a solution containing $10 \mu \mathrm{M} \mathrm{Fc}(\mathrm{MeOH})_{2}$ in Cell 1a. Error bars indicate the standard deviation of 5 repetitive measurements.

Another point likely to influence the analysis from CE is the type of "bridge" connector between Cell 1a and Cell 1b. Different materials were tested, including Pt sheet of different size, $\mathrm{Cu}$ wire and a classical salt bridge. As seen from Figure S8, there is no significant difference for both the charge from current integration on WE1 and that from $\mathrm{Cu}^{(0)}$ stripping from CE1, regardless of the material, the size and the conductor type (ionic or electronic). Therefore, we did not study the effect of "bridge" further in detail and used $\mathrm{Cu}$ wire for the entire work. Just to recall that a main consideration of the cell design is to reduce as much as possible the interfacial impedance between the "bridge" and the solutions to ensure that the cell voltage does not exceed the limit of the potentiostat $( \pm 10 \mathrm{~V})$, and that any cell configuration used here (three-electrode cell and two half-cells with either salt of metal bridges) gave exactly the same voltammetric response (Figure S1).

\subsection{The analytical figures of merit}

One already knows that prolonging the duration of applying the constant potential at WE1 leads to increasing overall charge passing through Cell 1, resulting also in increasing charges from CE1 (=WE2) stripping in Cell 2 (Figure 3). From the analytical point of view, it is now important to examine this "indirect preconcentration analysis" of $\mathrm{Fc}(\mathrm{MeOH})_{2}$ in a lower 
concentration range. Figure 7 shows that the charge from both current integration on WE1 and $\mathrm{Cu}$ stripping on CE1 (=WE2) increases with the electrolysis time at $+0.3 \mathrm{~V}$ in Cell 1 in the presence of $\mathrm{Fc}(\mathrm{MeOH})_{2}$ at 3, 6 and $10 \mu \mathrm{M}$, respectively, whereas the absence of probe (blank) leads to zero stripping charge as recorded from counter electrode (in comparison to significant background response for direct analysis at the working electrode). This confirms that $\mathrm{Fc}(\mathrm{MeOH})_{2}$ can also be indirectly "pre-concentrated" with time, indirectly through the electrodeposition of $\mathrm{Cu}$ on $\mathrm{CE} 1$ during its oxidation. Therefore, the concept of stripping may also be applicable here, and one may eventually analyse lower concentration of analyte by increasing the time. It allows a trade-off between the time and sensitivity of analysis.
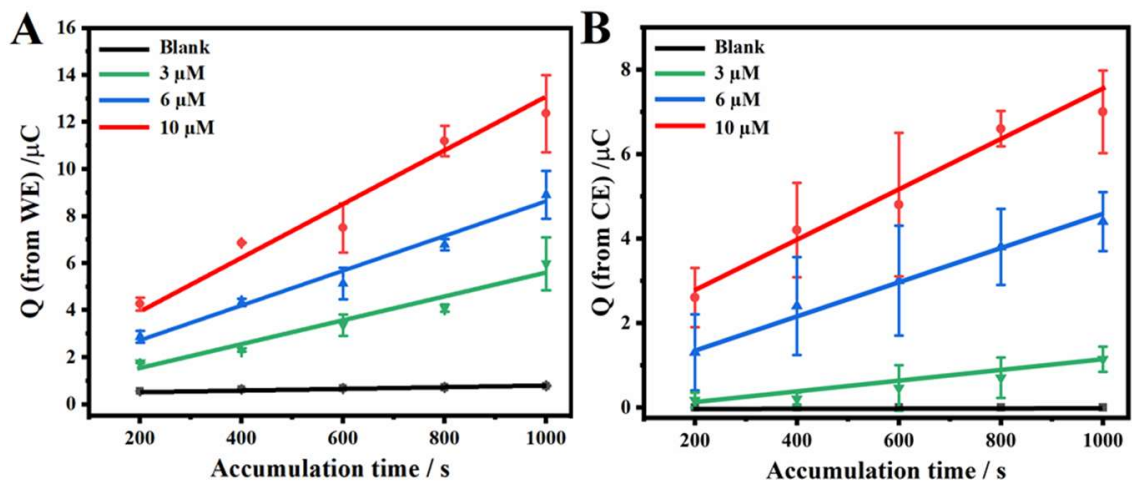

Figure 7. Variation of charge as a function of accumulation time (by applying $+0.3 \mathrm{~V}$ to WE1 for increasing times in blank or 3, 6 or $10 \mu \mathrm{M} \mathrm{Fc}(\mathrm{MeOH})_{2}$ solutions in Cell 1a), measured from current integration on WE1 in Cell 1 (A) and Cu stripping from CE1 (=WE2) in Cell 2. Error bars indicate the standard deviation of 5 repetitive measurements.

As an analytical method, it is important to establish a calibration curve for different concentration of analyte under fixed analytical conditions. Here, $+0.3 \mathrm{~V}$ vs. $\mathrm{Ag} / \mathrm{AgCl}$ was applied to WE1 for $800 \mathrm{~s}$, with concentration of $\mathrm{Fc}(\mathrm{MeOH})_{2}$ in Cell 1a from 0 to $10 \mu \mathrm{M}$, and $0.2 \mathrm{M} \mathrm{CuSO}_{4}$ at $\mathrm{pH} 2$ in Cell 1b. Two signals are considered for analysis: charge from current integration during the oxidation of $\mathrm{Fc}(\mathrm{MeOH})_{2}$ in Cell 1a, and charge from $\mathrm{Cu}$ stripping of CE1 in Cell 2. Figure 8A shows clearly different slopes for low concentrations, up to $1 \mu \mathrm{M}$, and for the concentration range from 1 to $10 \mu \mathrm{M}$. The blank solution also shows a signal of $c a$. $1 \mu \mathrm{C}$, which is very close to the signals from 0.1 and $0.2 \mu \mathrm{M}$ solutions. This blank signal arises from the non-Faradaic current, and is dominant in the solutions with low concentration of analyte, restricting the detection limit down to $0.4 \mu \mathrm{M}$ for such direct detection. Meanwhile, Figure 8B shows better linearity over the whole concentration range. Even at low concentration, the signals are still clearly distinguishable and analysable by fitting, with a limit of detection (LOD) estimated at $0.1 \mu \mathrm{M}\left(\mathrm{LOD}=3 S_{a} / b\right.$, where $S_{a}$ is the standard deviation of the 
response ( $\mathrm{n}=5)$ and $b$ is the slope of the calibration curve). With such optimal conditions, the blank signal is not detectable when measured by anodic stripping at the counter electrode. These phenomena make the $\mathrm{Cu}$ stripping signals from $\mathrm{CE} 1$ more favourable for analysing low concentrations of $\mathrm{Fc}(\mathrm{MeOH})_{2}$. This is likely because the counter electrode may serve as a filter for non-Faradaic charge. Finally, we also tested stirring the solution in Cell 1a (in order to accelerate mass transport of $\left.\mathrm{Fc}(\mathrm{MeOH})_{2}\right)$ and, besides noisier amperometric response, this resulted in an increase of sensitivity (stripping peaks almost 5 times larger than in quite solution, see Figure S9), but it does not contribute to lower LOD.
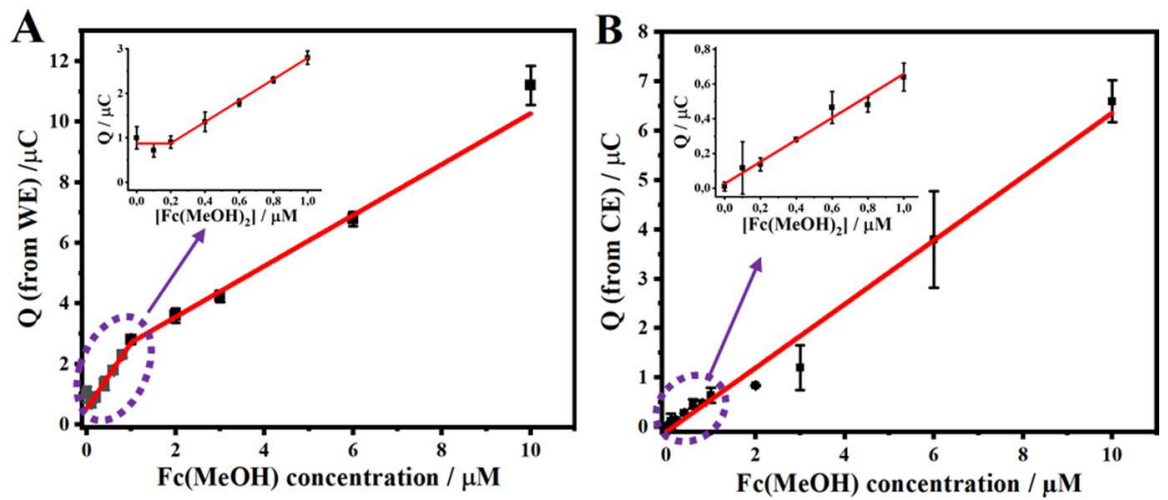

Figure 8. Calibration curves obtained from (A) working electrode and (B) counter electrode for detection of increasing concentrations of $\mathrm{Fc}(\mathrm{MeOH})_{2}$ in Cell 1a; potential applied to WE1: $+0.3 \mathrm{~V}$ vs. $\mathrm{Ag} / \mathrm{AgCl}$, for $800 \mathrm{~s}$; solution in Cell 1b: $0.2 \mathrm{M} \mathrm{CuSO}_{4}$ at $\mathrm{pH} 2$; error bars indicate the standard deviation of 5 experiments. Inset graphs show the enlarged calibration curves of $\mathrm{Fc}(\mathrm{MeOH})_{2}$ in the concentration range from 0 to $1 \mu \mathrm{M}$.

A major advantage of stripping analysis is that one may play with the "accumulation" time in finding a compromise between signal sensitivity and detection limit. In this work, from all the figures, it is seen that the charge from $\mathrm{Cu}$ stripping on CE1 (=WE2) is always lower than that from direct integration of current from WE1. This leads to a decrease in the apparent sensitivity fitted from Figure 8. Nevertheless, we would stress that the charge is already a processed signal, while the raw signal is the current. From Figure 2, it is clearly seen that the current from stripping is much higher in absolute value than that from either LSV or chronoamperometry. This makes the measurement more accurate, with the current signals more resolved from noise. It may explain the advantage in determining low concentrations as shown in Figure 8. Of course, for such reversible redox probe used here as model analyte, the method cannot compete with classical differential pulse voltammetry (with LOD of $0.17 \mu \mathrm{M}$, Figure S10) in terms of analysis speed, but it might be of interest for electroanalytical schemes involving very slow recognition/detection events, such as those encountered with molecularly 
imprinted electrodes, for instance. This would also contribute to induce more selectivity to the detection, which is here only related to the oxidation potential applied in Cell 1a.

In order to show that the method can be useful for determining other compounds, we tested it for another analyte (i.e., gentisic acid, an antioxidant molecule used in pharmaceutical industry [47]) by performing preconcentration for $300 \mathrm{~s}$, either in stirred or non-stirred media (Figure 9A). The calibration curves obtained in the sub- $\mu \mathrm{M}$ concentration range (Figure 9B) confirm the trends observed for $\mathrm{Fc}(\mathrm{MeOH})_{2}$ redox probe, with a sensitivity improved by ca. 4 times when stirring the solution in Cell 1a containing the gentisic acid analyte. LOD values determined from measuring the stripping signals from CE1 were $0.03 \mu \mathrm{M}$ and $0.04 \mu \mathrm{M}$, respectively with and without stirring; they are lower than for $\mathrm{Fc}(\mathrm{MeOH})_{2}$, most probably because gentisic acid is likely to adsorb on electrode surfaces [48] thus contributing to more effective preconcentration.
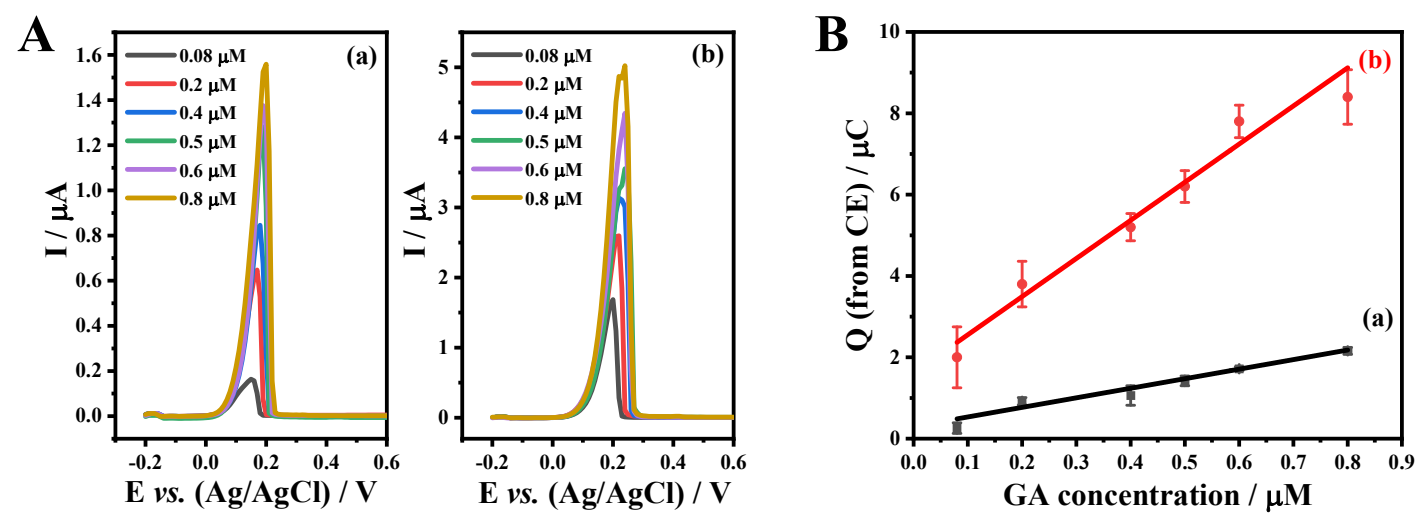

Figure 9. Anodic stripping signals recorded at counter electrode after transfer to Cell 2 (A) and corresponding calibration curves (B), for detection of increasing concentrations of gentisic acid (GA) from 0.08 to $8 \mu \mathrm{M}$ in Cell 1a, respectively without (a) or with stirring (b); potential applied to WE1: $+0.3 \mathrm{~V}$ vs. $\mathrm{Ag} / \mathrm{AgCl}$, for $300 \mathrm{~s}$; solution in Cell $1 \mathrm{~b}: 0.2 \mathrm{M} \mathrm{CuSO}_{4}$ at $\mathrm{pH} 2$; error bars in (B) indicate the standard deviation of 3 experiments.

\section{Conclusion}

In summary, we report a new method of electrochemical stripping analysis for target analytes that do not deposit or adsorb on the working electrode. This is achieved by capturing the stripping signals indirectly from counter electrode, from a metal deposit formed while oxidizing the analyte. An electrochemical cell is designed, with the working electrode and 
analyte in one compartment (Cell 1a) and a micro-disk counter electrode and $\mathrm{Cu}^{2+}$ species in another compartment (Cell 1b). The two compartments are connected with a metal or ionic "bridge". By applying an oxidative potential on working electrode, the analyte in Cell 1a is oxidized while $\mathrm{Cu}^{2+}$ is reduced and deposited on the counter electrode. The latter is then transferred to another cell (Cell 2) for determining by anodic stripping the amount of previously deposited $\mathrm{Cu}^{(0)}$, which is related to the current flow through Cell 1 and thus indirectly reflects the concentration of analyte. Instead of classical counter electrodes with large surface area, a micro-disk counter electrode is purposely selected for high polarization and low non-Faradaic charging. The effect of the size of counter electrode, the $\mathrm{Cu}^{2+}$ concentration and $\mathrm{pH}$ of the solution in Cell 1b, and the "bridge" connector were systematically studied. With optimal conditions, the $\mathrm{Cu}^{(0)}$ stripping charge from the counter electrode shows good linear relationship with the concentration of the model analyte $\left(\mathrm{Fc}(\mathrm{MeOH})_{2}\right)$ used here in Cell 1a, which was also confirmed for another analyte (gentisic acid). This method has merits in improving the resolution of current, as the stripping current (peak) is much more clearly defined than the differences in currents sampled during the direct oxidation of the probe. Besides, it may also reduce the background signal from blank solution by "filtering" the background signal (resulting from noise and non-Faradaic charge). Like in classical electrochemical stripping analysis, one may also prolong the oxidation ("accumulation") time or stir the preconcentration solution to enhance performance of analysis. This work extends the applications of stripping analysis and offers new possibilities for electroanalysis by capturing signals from counter electrode. 


\section{References}

[1] J. Wang, Analytical Electrochemistry, $3^{\text {rd }}$ Edition, Wiley-VCH, New York, 2006. https://doi.org/10.1002/0471790303.

[2] I. Švancara, K. Vytřas, K. Kalcher, A. Walcarius, J. Wang, Carbon paste electrodes in facts, numbers, and notes: A review on the occasion of the 50-years jubilee of carbon paste in electrochemistry and electroanalysis, Electroanalysis. 21 (2009) 7-28. https://doi.org/10.1002/elan.200804340.

[3] A.J. Bard, L.R. Faulkner, Electrochemical methods: fundamentals and applications, John Wiley and Sons, 2000. ISBN: 978-0-471-04372-0.

[4] P.T. Kissinger, W.R Heineman, Laboratory Techniques in Electroanalytical Chemistry, $2^{\text {nd }}$ Ed., CRC Press, Boca Raton, 2018. https://doi.org/10.1201/9781315274263.

[5] R. Holze, Experimental Electrochemistry: A Laboratory Textbook, $2^{\text {nd }}$ Ed., WileyVCH Verlag GmbH \& Co. KGaA, 2019. ISBN: 978-3-527-33524-4.

[6] E. Pungor; K. Tóth, Ion Selective Electrodes A Review, Anal. Sci. 3 (1987) 387-393. https://doi.org/10.2116/analsci.3.387.

[7] K.N. Mikhelson, Ion Selective Electrodes, Springer-Verlag, Berlin Heidelberg, 2013. ISBN 978-3-642-36886-8

[8] M.A. Pellitero, A. Shaver, N. Arroyo-Currás, Approaches for the electrochemical interrogation of DNA-based sensors: A critical review, J. Electrochem. Soc. 167 (2020) 037529. https://doi.org/10.1149/2.0292003JES.

[9] H. Ryu, D. Thompson, Y. Huang, B. Li, Y. Lei, Electrochemical sensors for nitrogen species: A review, Sensors Actuat. Rep. 2 (2020) 100022.

https://doi.org/10.1016/j.snr.2020.100022.

[10] K.L. Rahn, T.D. Rhoades, R.K. Anand, Alternating current voltammetry at a bipolar electrode with smartphone luminescence imaging for point of need sensing, ChemElectroChem 7 (2020) 1172-1181. https://doi.org/10.1002/celc.202000079.

[11] D. Ji, L. Liu, S. Li, C. Chen, Y. Lu, J. Wu, Q. Liu, Smartphone-based cyclic voltammetry system with graphene modified screen printed electrodes for glucose 
detection, Biosens. Bioelectron. 98 (2017) 449-456.

https://doi.org/10.1016/j.bios.2017.07.027.

[12] M.H.F. Taha, H. Ashraf, W. Caesarendra, A brief description of cyclic voltammetry transducer-based non-enzymatic glucose biosensor using synthesized graphene electrodes, Appl. Syst. Innov. 3 (2020) 32. https://doi.org/10.3390/asi3030032.

[13] T. Nasir, G. Herzog, L. Liu, M. Hébrant, C. Despas, A. Walcarius, Mesoporous silica thin films for improved electrochemical detection of paraquat, ACS Sensors 3 (2018) 484-493. https://doi.org/10.1021/acssensors.7b00920.

[14] Z. Stojek, Pulse Voltammetry, in F. Scholz (Ed.), Electroanalytical methods. Guide to experiments and applications, $2^{\text {nd }}$ Ed., Springer-Verlag, Berlin Heidelberg, 2010, Chap. II.2, pp. 107-119. https://doi.org/10.1007/978-3-642-02915-8.

[15] B. Dogan-Topal, S.A. Ozkan, B. Uslu, The analytical applications of square wave voltammetry on pharmaceutical analysis. Open Chem. Biomed. Methods J., 2010, 3, 56-73. https://doi.org/10.2174/1875038901003010056.

[16] K.K. LM Moretto, Environmental Analysis by Electrochemical Sensors and Biosensors, Springer New York, New York, NY, 2014. https://doi.org/10.1007/978-14939-0676-5.

[17] C. Batchelor-McAuley, E.J.F. Dickinson, N.V. Rees, K.E. Toghill, R.G. Compton, New Electrochemical Methods, Anal. Chem. 84 (2012) 669-684. https://doi.org/dx.doi.org/10.1021/ac2026767.

[18] J. Wang, Electrochemical glucose biosensors, Chem. Rev. 108 (2008) 814-825. https://doi.org/10.1021/cr068123a.

[19] V.B. Juska, M.E. Pemble, A critical review of electrochemical glucose sensing: Evolution of biosensor platforms based on advanced nanosystems, Sensors 20 (2020) 6013. https://doi.org/10.3390/s20216013.

[20] E.-H. Yoo, S.-Y. Lee, Glucose biosensors: An overview of use in clinical practice, Sensors 10 (2010) 4558-4576. https://doi.org/10.3390/s100504558.

[21] J. Wang, Stripping analysis: principles, instrumentation, and applications, VCH Publishers, Inc., Deerfield Beach, Florida, 1985. https://doi.org/10.1002/ange.19860980840. 
[22] S.B. Hocevar, I. Švancara, B. Ogorevc, K. Vytřas, Antimony film electrode for electrochemical stripping analysis, Anal. Chem. 79 (2007) 8639-8643. https://doi.org/10.1021/ac070478m.

[23] K. Brainina, E. Neyman, Electroanalytical Stripping Methods, John Wiley \& Sons Inc, 1994. ISBN: 978-0-471-59506-9.

[24] R. Kalvoda, Review of adsorptive stripping voltammetry - assessment and prospects, Fresenius. J. Anal. Chem. 349 (1994) 565-570. https://doi.org/10.1007/BF00323458.

[25] G. Herzog, V. Beni, Stripping voltammetry at micro-interface arrays: A review, Anal. Chim. Acta. 769 (2013) 10-21. https://doi.org/10.1016/j.aca.2012.12.031.

[26] R. Murray, Molecular design of electrode surfaces, in Techniques of chemistry, Vol. 22, Wiley, Chichester 1992. ISBN: 978-0471557739.

[27] A. Walcarius, M. Etienne, G. Herzog, V. Urbanova, N. Vilà, in Environmental Analysis by Electrochemical Sensors and Biosensors, K. Kalcher and L. Moretto (eds.), Springer, 2014, Vol. 1, Chap. 16, pp. 403-495. https://doi.org/10.1007/978-14939-0676-5_16.

[28] R.W. Murray, A.G. Ewing, R.A. Durst, Chemically modified electrodes Molecular design for electroanalysis, Anal. Chem. 1987, 59, 5, 379A-390A. https://doi.org/10.1021/ac00132a721.

[29] I. Švancara, K. Kalcher, A. Walcarius, K. Vytřas, Electroanalysis with Carbon Paste Electrodes, CRC Press, 2012. https://doi.org/10.1201/b11478.

[30] B. Cui, P. Liu, X. Liu, S. Li, Z. Zhang, Molecularly imprinted polymers for electrochemical detection and analysis: progress and perspectives, J. Mater. Res. Technol. 2020, 9, 12568-12584. https://doi.org/10.1016/j.jmrt.2020.08.052.

[31] P. Rebelo, E. Costa-Rama, I. Seguro, J. G. Pacheco, H. P. A. Nouws, M. N. D. S. Cordeiro, C. Delerue-Matos, Molecularly imprinted polymer-based electrochemical sensors for environmental analysis, Biosens. Bioelectron. 2021, 172, 112719. https://doi.org/10.1016/j.bios.2020.112719

[32] X. Niu, M. Lan, H. Zhao, C. Chen, Y. Li, X. Zhu, Review: Electrochemical stripping analysis of trace heavy metals using screen-printed electrodes, Anal. Lett. 46 (2013) 2479-2502. https://doi.org/10.1080/00032719.2013.805416. 
[33] M. Sýs, A.S. Farag, I. Švancara, Extractive stripping voltammetry at carbon paste electrodes for determination of biologically active organic compounds, Monatsh. Chem. 150 (2019) 373-386. https://doi.org/10.1007/s00706-018-2346-0.

[34] A.H. Alghamdi, Applications of stripping voltammetric techniques in food analysis, Arab. J. Chem. 3 (2010) 1-7. https://doi.org/10.1016/j.arabjc.2009.12.001.

[35] S. Cheraghi, M.A. Taher, M. Bijad, H. Sadeghifar, A review: Stripping voltammetric methods as a high sensitive strategy for trace analysis of ions, pharmaceutical and food samples, Curr. Anal. Chem. 13 (2017) 5-12. https://doi.org/10.2174/1573411012666160601130929.

[36] J.C. Myland, K.B. Oldham, Uncompensated resistance. 1. The effect of cell geometry, Anal. Chem. 72 (2000) 3972-3980. https://doi.org/10.1021/ac0001535.

[37] Y. Gao, X. Ding, J. Liu, L. Wang, Z. Lu, L. Li, L. Sun, Visible light driven water splitting in a molecular device with unprecedentedly high photocurrent density, J. Am. Chem. Soc. 135 (2013) 4219-4222. https://doi.org/10.1021/ja400402d.

[38] R. Djoumer, A. Anne, A. Chovin, C. Demaille, C. Dejous, H. Hallil, J.L. Lachaud, Converting any Faradaic current generated at an electrode under potentiostatic control into a remote fluorescence signal, Anal. Chem. 91 (2019) 6775-6782. https://doi.org/10.1021/acs.analchem.9b00851.

[39] O. Yassine, O. Shekhah, A.H. Assen, Y. Belmabkhout, K.N. Salama, M. Eddaoudi, $\mathrm{H}_{2} \mathrm{~S}$ sensors: Fumarate-based fcu-MOF thin film grown on a capacitive interdigitated electrode, Angew. Chem., Int. Ed. 128 (2016) 16111-16115. https://doi.org/10.1002/ange.201608780.

[40] R.R. Kamath, M.J. Madou, Three-dimensional carbon interdigitated electrode arrays for redox-amplification, Anal. Chem. 86 (2014) 2963-2971. https://doi.org/10.1021/ac4033356.

[41] J. He, L. You, D.T. Tran, J. Mei, Low-temperature thermally annealed niobium oxide thin films as a minimally color changing ion storage layer in solution-processed polymer electrochromic devices, ACS Appl. Mater. Interfaces. 11 (2019) 4169-4177. https://doi.org/10.1021/acsami.8b16154.

[42] W. Xu, K. Fu, C. Ma, P.W. Bohn, Closed bipolar electrode-enabled dual-cell 
electrochromic detectors for chemical sensing, Analyst 141 (2016) 6018-6024. https://doi.org/10.1039/C6AN01415A.

[43] J.N. Murray, Electrochemical test methods for evaluating organic coatings on metals: an update. Part I. Introduction and generalities regarding electrochemical testing of organic coatings. Prog. Org. Coat. 30 (1997) 225-233. https://doi.org/10.1016/S03009440(96)00677-7

[44] S.E. Fosdick, R.M. Crooks, Bipolar electrodes for rapid screening of electrocatalysts, J. Am. Chem. Soc. 134 (2012) 863-866. https://doi.org/10.1021/ja210354m.

[45] R.A. Cottis, Electrochemical methods, Shreir's Corros. 2 (2010) 1341-1373. https://doi.org/10.1016/B978-044452787-5.00068-8.

[46] A. Katagiri, H. Inoue, N. Ogure, Cathodic polarization of copper electrode in $\mathrm{CuCN}-$ $\mathrm{KCN}$ solutions and the current distribution for copper deposition on grooved substrates, J. Appl. Electrochem. 27 (1997) 529-538. https://doi.org/10.1023/A:1018490410509.

[47] A. Mardani-Ghahfarokhi, R. Farhoosh, Antioxidant activity and mechanism of inhibitory action of gentisic and $\alpha$-resorcylic acids, Sci. Rep. 10 (2020) 19487. https://doi.org/10.1038/s41598-020-76620-2.

[48] P.-X. Dai, T. Chen, D. Wang, L.-J. Wan, Potential dependent adsorption geometry of 2,5-dihydroxybenzoic acid on a $\mathrm{Au}(111)$ surface: An in situ electrochemical scanning tunneling microscopy study, J. Phys. Chem. C 116 (2012 6208-6214. dx.doi.org/10.1021/jp210119m.

\section{ACKNOWLEDGMENTS}

Q.L. acknowledges financial support from the China Scholarship Council for her doctoral studies. 